\title{
Quantitative determination of FAM3D plasma protein in type 2 diabetes mellitus
}

\author{
José Antônio Januário Neves*, Daniel Giannella Neto \\ From 20th Brazilian Diabetes Society Congress \\ Porto Alegre, Brazil. 11-18 November 2015
}

\section{Background}

Among the new cytokine Family with Sequence Similarity 3 (FAM3), a subfamily of proteins similar to cytokines known as FAM3D was identified. FAM3D is predominantly expressed in the gastrointestinal tract of normal individuals. Plasma concentrations of FAM3D range according to the nutritional status presenting a postprandial increase and a reduction in the later postabsorptive period. It might be speculated that FAM3D is an inhibitor of insulin secretion, as it has been observed a significant increase in patients with pancreatic adenocarcinoma associated with T2D.

\section{Aims \\ Quantitatively determine the plasma concentration of FAM3D, in a group of patients with T2D and comparing with patients with pre-Type 2 Diabetes Mellitus (pT2D) and Control (CTRL) individuals paired according to gen- der, age and body mass index in order to better elucidate the physiology of FAM3D as well as its pathophysiologi- cal role in T2D.}

\section{Materials and methods}

We selected 90 patients comprising 15 male and 14 females diagnosed with T2D; 12 male and 15 female diagnosed pT2D; and 7 male and 9 female CTRL. Seventeen patients were excluded according to the inclusion and exclusion criteria. In total, 73 patients were included. All were submitted to measurement of anthropometric and biochemical tests, including HOMA-IR calculation and the determination of plasma concentrations of FAM3D by ELISA. The Mann-Whitney tests were used in the comparison of study groups, and the regression coefficient $\mathrm{P}$ of Spearman was calculated on correlation between plasma concentrations of
FAM3D and other anthropometric and biochemical variables. The level of statistical significance was set at $\mathrm{p}<0.05$.

\section{Results}

Among the groups there were no significant difference in the concentration of FAM3D, and the median $\pm \mathrm{Q}$ for the CTRL group $(24.92 \mathrm{ng} / \mathrm{mL} \pm 9.11) ; \mathrm{pT} 2 \mathrm{D}(14.65 \mathrm{ng} / \mathrm{mL}$ $\pm 6.02)$ and T2D $(19.87 \mathrm{ng} / \mathrm{mL} \pm 5.39)$. The group of DM2 patients on sulfonylurea $(23.42 \mathrm{ng} / \mathrm{mL} \pm 6.1)$ had higher values compared to the group treated with other oral antidiabetic drugs (14.9 $\mathrm{ng} / \mathrm{mL} \pm 7.30), \mathrm{p}<0.05$.

\section{Conclusions}

There was no correlation of FAM3D between groups. Patients with T2D on sulfonylurea presented a higher concentration of FAM3D when compared with T2D patients treated with other oral antidiabetic drugs. Although further studies are necessary, the increased concentrations of FMA3D in patients with T2D on sulfonylurea could be due to the inhibitory effect of the secretagogue on FAM3D.

Published: 11 November 2015

doi:10.1186/1758-5996-7-S1-A137

Cite this article as: Neves and Neto: Quantitative determination of

FAM3D plasma protein in type 2 diabetes mellitus. Diabetology \& Metabolic Syndrome 2015 7(Suppl 1):A137.

* Correspondence: joseajneves@yahoo.com.br

Universidade Nove de Julho, Manhuaçu, Brazil

(C) 2015 Neves et al. This is an Open Access article distributed under the terms of the Creative Commons Attribution License (http:// creativecommons.org/licenses/by/4.0), which permits unrestricted use, distribution, and reproduction in any medium, provided the original work is properly cited. The Creative Commons Public Domain Dedication waiver (http://creativecommons.org/publicdomain/ zero/1.0/) applies to the data made available in this article, unless otherwise stated. 